\title{
SINDROM PICKWICKIAN-SINDROM HIPOVENTILASI PADA OBESITAS: LAPORAN KASUS DENGAN PENDEKATAN DIAGNOSIS KLINIS
}

\author{
OBESITY HYPOVENTILATION SYNDROME-THE PICKWICKIAN SYNDROME \\ A CLINICALLY DIAGNOSTIC APPROACH CASE REPORT
}

Ni Luh Putu Dirasandhi Semedi Putri, * Desak Ketut Indrasari Utami, * I Gusti Ngurah Budiarsa, * Sri Yenni Trisnawati*

\begin{abstract}
A 36-year-old man complained about snoring in the past 3 years with a very loud snoring interspersed with choking. This recurs throughout the night, thus, he often experiences excessive drowsiness during the day. He also experienced generalized tonic-clonic seizure in the past six months during sleeping at night or immediately after wake up in the morning. It happened three to four times a week. In the past one month he also experienced a morning headache. He was classified as morbid obesity and had $47.2 \mathrm{~cm}$ wide of neck circumference. STOP-BANG score and Snoring Severity Score (SSS) indicated high risk of Obstructive Sleep Apnea. Apnea Hypopnea Index (AHI) was 55.5. The Epworth Sleepiness Scale (ESS) score was 15 indicated to have an excessive sleepiness during the day. Blood gas analysis showed a hypercapnia and chronic hypoventilation condition characterized by the increasing of pCO2 and HCO3- with normal pH. A complete blood count examination showed polycythemia. The patient was diagnosed as Obesity Hypoventilation Syndrome (OHS) based on obesity, OSA, and chronic hypoventilation. With a limited gold standard diagnostic tools, such as polysomnography (PSG), a clinical approach using sleep tools and blood gas analysis to detect early stage OHS still can be made.
\end{abstract}

Keywords: Chronic hypoventilation, morbid obesity, Obesity Hypoventilation Syndrome, obstructive sleep apnea

\begin{abstract}
ABSTRAK
Seorang laki-laki 36 tahun dikeluhkan selalu mendengkur sejak 3 tahun dengan suara dengkuran yang sangat keras diselingi tersedak. Hal ini berulang sepanjang malam hingga pasien sering mengantuk berlebihan di siang hari. Pasien juga mengalami bangkitan umum tonik klonik sejak enam bulan, saat sedang tidur malam hari atau segera setelah terbangun di pagi hari. Sejak 1 bulan, pasien mengeluh sakit kepala saat bangun pagi. Pasien tergolong morbid obesity dan lingkar leher 47,2cm. Skor STOP-BANG dan skor Snoring Severity Score (SSS) menunjukkan risiko tinggi obstructive sleep apneu (OSA), serta Apnea Hypopnea Index (AHI) adalah 55,5. Skor Epworth Sleepiness Scale (ESS) 15 menunjukkan mengantuk berlebihan di siang hari. Pemeriksaan analisis gas darah didapatkan kondisi hiperkapnia dan hipoventilasi kronik berupa peningkatan $\mathrm{pCO} 2$ dan $\mathrm{HCO}^{-}$dengan $\mathrm{pH}$ darah cenderung normal. Pemeriksaan darah lengkap menunjukkan polisitemia. Pasien didiagnosis sebagai Sindrom Hipoventilasi pada Obesitas (SHO) karena adanya obesitas, OSA, dan hipoventilasi kronik. Meskipun memiliki keterbatasan alat diagnostik baku emas seperti polisomnografi (PSG), namun pendekatan klinis beserta sleep tools dan analisis gas darah dapat digunakan untuk mendeteksi dini SHO.
\end{abstract}

Kata kunci: Hipoventilasi kronik, morbid obesity, obesity Hypoventilation Syndrome, obstructive sleep apneu

*Departemen Ilmu Penyakit Saraf FK Universitas Udayana/RSUP Sanglah, Denpasar. Korespondensi: dira_sandhi@yahoo.com.

\section{PENDAHULUAN}

Sindrom Hipoventilasi pada Obesitas (SHO) atau sindrom Pickwikian merupakan kumpulan gejala yang terdiri dari obesitas, gangguan tidur terkait pernapasan, dan hipoventilasi kronik pada siang hari, setelah mengeksklusi penyebab hipoventilasi lainnya, seperti penyakit pulmonal, deformitas dinding dada, hipotiroid, atau penyakit neuromuskular. ${ }^{1-2}$ Prevalensi SHO sebesar $0,15-0,31 \%$ pada populasi dewasa dan $19-31 \%$ pada kelompok obesitas. ${ }^{2}$

Patogenesis SHO bersifat multifaktorial, yaitu peningkatan beban sistem pernapasan, penurunan central respiratory drive, gangguan tidur terkait pernapasan, dan resistensi leptin. ${ }^{2-4}$ Diagnosis pasti SHO berdasarkan polisomnografi (PSG) untuk mengevaluasi stadium tidur, saturasi oksigen, aliran udara pernapasan, gerakan napas, dan elektrokardiografi (EKG).

Konsekuensi diagnosis SHO berkorelasi dengan durasi rawat inap yang lebih lama, biaya perawatan kesehatan, komorbiditas penyakit kardiorespirasi, dan angka mortalitas serta morbiditas yang lebih tinggi dibandingkan individu obesitas tanpa hipoventilasi. Mortalitas SHO mencapai $23 \%$ dalam waktu 18 bulan setelah pertama kali terdiagnosis jika tidak mendapat terapi. ${ }^{5}$ 
Keluhan utama pasien SHO datang ke rumah sakit $80 \%$ adalah sesak napas dan diagnosis SHO biasanya baru ditegakkan setelah pasien berkali-kali dirawat inap atas indikasi sesak napas. Beberapa studi menunjukkan SHO sering terdiagnosis sebagai kelainan paru atau jantung. ${ }^{2}$

Studi observasional tahun 2016 menemukan hanya $17 \%$ kasus yang terdiagnosis SHO dengan tepat, sedangkan sisanya terdiagnosis sebagai penyakit paru obstruktif dan gagal jantung kongestif. ${ }^{1}$ Fasilitas polisomnografi yang terbatas juga berdampak pada keterlambatan penegakan diagnosis, sehingga meningkatkan angka mortalitas dan morbiditas SHO. Oleh karena itu, diperlukan kemampuan penegakan diagnosis secara klinis untuk deteksi dini diagnosis SHO.

\section{KASUS}

Laki-laki, 36 tahun, dikeluhkan sering mendengkur sejak 3 tahun terakhir yang semakin lama semakin sering. Suara dengkuran sangat keras sampai terdengar ke kamar sebelahnya dan mengganggu istrinya. Saat tidur, pasien sering tibatiba berhenti mendengkur beberapa detik, kemudian seperti tersedak, lalu mendengkur kembali. Dengkuran terjadi tidak dipengaruhi dengan posisi tidur. Hal ini terjadi setiap hari berulang-ulang sepanjang malam sampai tidak terhitung frekuensinya dan menyebabkan tidur malam pasien terganggu, sehingga pasien mengantuk yang berlebihan pada siang hari dan tertidur saat melakukan aktivitas.

Sejak enam bulan terakhir pasien mengalami kejang dengan pola bangkitan umum tonik klonik selama sekitar 2 menit, setelah itu pasien tampak kebingungan lalu sadar kembali. Kejang selalu terjadi dini hari saat pasien tidur antara pukul 03.00 sampai 05.00 atau sesaat setelah bangun tidur di pagi hari. Frekuensi awal kejang adalah 1-2 kali seminggu, meningkat menjadi 3-4 kali seminggu.

Pasien juga mengeluhkan nyeri kepala saat bangun pagi sejak satu bulan yang lalu, hampir setiap hari. Nyeri dirasakan dari bagian belakang hingga ke seluruh bagian kepala dengan intensitas nyeri ringan sedang berdasarkan Numeric Rating Scale (NRS) $2-4$.
Hasil pemeriksaan fisik didapatkan indeks massa tubuh (IMT) adalah $51,9 \mathrm{~kg} / \mathrm{m}^{2}$ dengan lingkar leher 47,2cm. Skor STOP-BANG Sleep Apneu Questionaire didapatkan skor 7 yang mengindikasikan risiko tinggi obstructive sleep apneu (OSA), skor Snoring Severity Score (SSS) 7, rerata Apnea Hypopnea Index (AHI) 55,5, dan skor Epworth Sleepiness Scale (ESS) 15.

Pemeriksaan analisis gas darah (AGD) dikerjakan setiap pagi selama 7 hari perawatan, saat pasien tidak tidur dan tidak mengalami keluhan sesak. Didapatkan peningkatan $\mathrm{pCO}_{2}$ dengan variasi $52,3-71,7 \mathrm{mmHg}$ dan $\mathrm{HCO}_{3}$ antara $30,0-380 \mathrm{mmol} / \mathrm{L}$. Pasien juga mengalami polisitemia dengan hasil hematokrit antara $62,6-66,7 \%$ dan kadar hemoglobin antara $16,69-18,9 \mathrm{~g} / \mathrm{dL}$. Pemeriksaan foto toraks dan EKG mengesankan kardiomegali. Pemeriksaan elektroensefalografi (EEG) dan fungsi tiroid dalam batas normal. Terapi spesifik pada pasien ini belum dilakukan terkait pembiayaan.

\section{PEMBAHASAN}

Pasien ini memiliki keluhan utama mengalami dengkuran yang dirasa mengganggu, baik bagi pasien maupun istrinya. Pasien juga mengalami henti napas saat tidur, adanya periode rasa tercekik atau tersedak saat tidur, sehingga tidur terasa tidak menyegarkan dan menyebabkan mengantuk berlebihan saat siang hari. Klinis tidur dengan dengkuran seperti ini bersifat patologis yang dapat diduga sebagai suatu gangguan tidur mengarah ke OSA.

Rumah Sakit Umum Pusat Sanglah saat ini belum memiliki fasilitas polisomnografi, sehingga diagnosis gangguan tidur dilakukan dengan pendekatan klinis menggunakan berbagai skoring. Hasil pemeriksaan pada pasien ini mengarah kepada diagnosis OSA berdasarkan hasil skoring STOPBANG (7), SSS (7), AHI (55,5), dan ESS (15). Penelitian Chung dkk pada 667 subjek obesitas menyimpulkan bahwa STOP-BANG merupakan alat prediksi OSA yang valid pada kelompok obesitas dan morbid obesity dengan sensitivitas $87 \%$ serta spesifisitas $81 \%$. Skor AHI $>30$ menunjukkan kemungkinan OSA berat. ${ }^{9}$

Penelitian Morris dkk pada 211 pasien, menggunakan skor SSS dan IMT sebagai dua 
prediktor paling akurat untuk mendeteksi OSA, dengan sensitivitas $97,4 \%$, spesifisitas $40 \%$, positive predictive value $82,3 \%$ dan negative predictive value $84,2 \% .^{10}$ Individu dikatakan berisiko tinggi OSA jika total $\mathrm{SSS} \geq 7$ atau $\mathrm{IMT} \geq 32 .{ }^{10}$ Berdasarkan kriteria WHO tahun 2000, pasien tergolong obesitas derajat III (morbid obesity). ${ }^{6}$

Indeks massa tubuh berkorelasi positif dengan persentase lemak tubuh, lingkar pinggang, dan rasio pinggang serta pinggul. Distribusi lemak tubuh yang berlebihan pada tubuh berdampak pada volume paru. Peningkatan usaha pernapasan dialami oleh penderita obesitas untuk menggerakkan dinding toraks dan abdomen yang dilapisi oleh lemak yang tebal. Kemampuan kompensasi yang sudah melewati batas akan menyebabkan reduksi dari kapasitas paru total, kapasitas vital paru, kapasitas residual fungsional, dan peningkatan volume residual. ${ }^{7}$ Berdasarkan teori tersebut, pada kasus ini didapatkan pasien berisiko tinggi OSA.

Pemeriksaan klinis yang juga penting adalah pemeriksaan lingkar leher. Lingkar leher $>17$ inci berisiko meningkatkan AHI, dan berkorelasi positif dengan peningkatan serum bikarbonat yang menunjukkan suatu kondisi hipoventilasi. ${ }^{8}$ Pasien dilakukan pemeriksaan AGD yang menunjang adanya hipoventilasi kronik berupa kondisi hiperkapnia kronik dengan hasil $\mathrm{pCO}_{2}$ selalu di atas $45 \mathrm{mmHg}$ dan bikarbonat serum di atas $27 \mathrm{mmol} / \mathrm{L}$.

Pasien didiagnosis sebagai SHO berdasarkan adanya obesitas, OSA, dan hipoventilasi kronik. Gejala klinis dari SHO adalah gangguan tidur terkait pernapasan, yaitu 90\% berupa OSA. ${ }^{1}$ Obesitas, khususnya morbid obesity, merupakan faktor predominan terjadinya SHO. Studi pada 167 subjek dengan morbid obesity, 76,6\% diantaranya menderita SHO. ${ }^{5}$ Studi lain juga menunjukkan tingginya prevalensi SHO diantara kelompok obesitas, yaitu $79,9 \%{ }^{1}$

Peningkatan $\mathrm{pCO} 2$ dengan $\mathrm{pH}$ darah yang normal atau sedikit menurun akibat adanya proses kompensasi renal dan peningkatan bikarbonat serum menunjukkan asidosis respirasi kronik akibat hiperkapnia. Macavei dkk mendapatkan bahwa kadar serum bikarbonat $\geq 27 \mathrm{mmol} / \mathrm{L}$ merupakan prediktor diagnostik SHO dengan sensitivitas $85,7 \%$ dan spesifisitas $89,5 \%{ }^{5}$

Penelitian lain menunjukkan kadar serum bikarbonat $\geq 27 \mathrm{mmol} / \mathrm{L}$ memiliki sensitivitas $88,1 \%$ dan spesifisitas 73,1\% untuk mendiagnosis $\mathrm{SHO}{ }^{8}$ Data mengenai kadar $\mathrm{pCO}_{2}$ sebagai prediktor $\mathrm{SHO}$ belum tersedia. Pasien juga mengalami polisitemia yang merupakan dampak sekunder akibat penurunan oksigenasi jaringan akibat sindrom hipoventilasi. ${ }^{11}$

Salah satu gejala lain pada pasien ini adalah adanya epilepsy around sleep. Episode bangkitan ini dicurigai sebagai akibat dari hipoksia pada sel neuron karena periode apneu yang dialami saat tidur. Tipe bangkitan umum tonik klonik pada pasien SHO biasanya terjadi sesaat setelah terbangun dari tidur dan terjadi lebih sering di malam hari, sesuai dengan frekuensi apneu yang sering terjadi. Sekitar $50 \%$ hasil EEG pada pasien SHO dengan kecurigaan epilepsi akan normal, ${ }^{3}$ sesuai dengan hasil EEG pada pasien ini.

Nyeri kepala yang dialami oleh pasien juga diprediksi merupakan nyeri kepala terkait gangguan tidur, dalam hal ini adalah SHO. Patofisiologi nyeri kepala diperkirakan berkorelasi dengan desaturasi oksigen. Prediktor terjadinya nyeri kepala pada SHO adalah saturasi oksigen di bawah $90 \%$, penurunan saturasi sebesar 5,9\%; dan rerata saturasi oksigen $80,9 \%{ }^{4}$ Rasa mengantuk yang berlebihan di siang hari juga diprediksi terkait dengan episode apneu di malam hari yang berulang-ulang, sehingga kualitas tidur malam pasien buruk. Hal ini berakibat bangun di pagi hari menjadi tidak segar dan mengantuk berlebihan di siang hari. ${ }^{4}$ Kumpulan gejala klinis pada kasus ini, mendukung adanya kondisi hiperkapnia dan indikasi gangguan tidur sepanjang malam. ${ }^{12}$

\section{KESIMPULAN}

Diagnosis SHO dapat dideteksi dini dengan memahami gejala klinis utama, yaitu obesitas, tanda-tanda hipoventilasi kronik, dan sleep disorder breathing serta gejala lainnya seperti epilepsi, nyeri kepala, serta rasa mengantuk berlebihan di siang hari. Hal ini ditunjang dengan alat diagnostik lainnya berupa sleep tools serta pemeriksaan laboratorium dan analisis gas darah. 


\section{DAFTAR PUSTAKA}

1. Shetty S, Parthasarathy S. Obesity hypoventilation syndrome. Curr Pulmonol Rep. 2015;4(1):42-55.

2. Balachandran JS, Massa JF, Mokhlesi B. Obesity hypoventilation syndrome epidemiology and diagnosis. Sleep Med Clin. 2014;9(3):341-7.

3. Marik PE. The malignant obesity hypoventilation syndrome (MOHS). Obes Rev. 2012;13(10):902-9.

4. Egea-Sataolalla C, Javaheri S. Obesity hypoventilation syndrome. Curr Sleep Medicine Rep. 2016(2):12-19.

5. Macavei VM, Spurling KJ, Loft J, Makker HK. Dignostic predictors of obesity-hypoventilation syndrome in patients suspected of having sleep disordered breathing. J Clin Sleep Med. 2013;9(9):879-84.

6. Aktar N, Kabir-Qureshi, Shahid-Ferdous H. Obesity: a review of pathogenesis and management strategies in adult. Delta Med Col J. 2017(5)1:35-48.

7. Liu C, Chen MS, Yu H. The relationship between obstructive sleep apnea and obesity hypoventilation syndrome: a systematic review and metaanalysis.
Oncotarget. 2017;54(8):93168-78.

8. Bingol Z, Pihtili A, Cagatay P, Okumus G, Kiyan E. Clinical predictors of obesity hypoventilation syndrome in obese subjects with obstructive sleep apnea. Respir Care. 2015;60(5):666-72.

9. Chung F, Yang Y, Liao P. Predictive performance of the STOP-BANG score for identifying obstructive sleep apnea in obese patients. Obes Surg. 2013;23(12):2050-7.

10. Morris LGT, Kleinberger A, Lee KC, Liberatore LA, Burschtin O. Rapid risk stratification for obstructive sleep apnea, based on snoring severity and body mass index. Otolaryngol Head Neck Surg. 2008;139(5):615-8.

11. Wang YY, Han F. Polycythemia, ablepsia, and obesity hypoventilation syndrome: a case report. Chinese Medical Journal. 2015;128(20):2815.

12. Nguyen-Michel VH, Pallanca O, Navarro V, Dupont S, Baulac M, Adam C. How are epileptic events linked to obstructive sleep apneas in epilepsy? Seizure. 2015(24):121-23. 